\title{
The privilege against self-incrimination in truth commission administered accountability initiatives
}

Article

Accepted Version

Bisset, A. (2017) The privilege against self-incrimination in truth commission administered accountability initiatives. Leiden Journal of International Law, 30 (1). pp. 155-176. ISSN 1478-9698 doi: https://doi.org/10.1017/S0922156516000613 Available at https://centaur.reading.ac.uk/66019/

It is advisable to refer to the publisher's version if you intend to cite from the work. See Guidance on citing.

To link to this article DOI: http://dx.doi.org/10.1017/S0922156516000613

Publisher: Cambridge University Press

All outputs in CentAUR are protected by Intellectual Property Rights law, including copyright law. Copyright and IPR is retained by the creators or other copyright holders. Terms and conditions for use of this material are defined in the End User Agreement.

$\underline{\text { www.reading.ac.uk/centaur }}$ 
Central Archive at the University of Reading

Reading's research outputs online 


\title{
The Privilege Against Self-Incrimination in
}

\section{Truth Commission Administered Accountability Initiatives}

\begin{abstract}
In recent times, transitional justice practice has increasingly seen truth commissions tasked with administering accountability programmes, distinct from and in addition to their traditional truth-seeking role. Such accountability schemes typically take the form of granting or recommending amnesty for those who disclose involvement in past crimes or facilitating reintegration on the basis of similar disclosures. Selfincriminating disclosures made in the course of traditional truth commission proceedings generally attract a robust set of legal safeguards. However, the protections within transitional accountability schemes administered by truth commissions tend to be less stringent. This article explores this anomaly, focusing particularly on the extent to which the privilege against self-incrimination is protected within truth commission administered accountability programmes. It considers the programmes operated to date, and the levels of protection afforded, and demonstrates a lack of consistent practice in the safeguarding of individual rights within these programmes. It examines international legal standards on the privilege against selfincrimination and questions whether the procedures operated by accountability programmes can be reconciled with international norms in order to protect those who make self-incriminating disclosures within accountability initiatives. The article argues that a failure to ensure individual rights against self-incrimination risks compromising the efficacy of the programmes themselves and the contribution that they can make to long term peace and reconciliation in transitional states.
\end{abstract}




\section{Key words}

Truth commissions, accountability schemes, self-incrimination

\section{Introduction}

Ensuring individual rights in truth commission proceedings has become an important aspect of mandate design and operational practice. Since the South African Truth and Reconciliation Commission (TRC) was challenged on the fairness and impartiality of its proceedings, ${ }^{1}$ truth commissions have routinely been created with procedural safeguards and guarantees of due process governing their operations. ${ }^{2}$ These procedural protections are not replicated in the accountability programmes now frequently administered by truth commissions, which most often involve truth telling in exchange for grants of or recommendations for amnesty. Those who participate in these initiatives do not seem to be protected by the same network of legal safeguards, despite the fact that the outcomes of these programmes might have significant legal ramifications. While the outcome of traditional truth commission proceedings might be findings of factual responsibility for or involvement in past violations, albeit with

\footnotetext{
${ }^{1}$ Truth and Reconciliation Commission of South Africa Report, (2002), Vol. 1, Ch. 7; Vol. 6, Section 1, Ch. 4 .

${ }^{2}$ See: UNTAET Regulation No. 2001/10 on the Establishment of a Commission for Reception, Truth and Reconciliation in East Timor, UN Doc. UNTAET/REG/2001/10, 13 July 2001, s. 17; Kenya, Truth Justice and Reconciliation Commission Act 2008, s.28; Witness to Truth: Report of the Sierra Leone Truth and Reconciliation Commission, (2004), Vol. 1, Ch. 5, 151, 154.
} 
implications for reputation rights, ${ }^{3}$ no civil or criminal repercussions flow directly from such findings. In contrast, the outcome of accountability programmes may be referral to prosecuting authorities and the recommendation of initiation of criminal proceedings, raising questions as to whether, and in what ways, incriminating disclosures made during the course of accountability proceedings might then be made available to and utilized by prosecutorial bodies. Indeed, in some contexts, accountability schemes have been predicated on the assumption that where, for example, amnesty is not granted prosecutions will follow. ${ }^{4}$ In light of this contrast, it is striking that truth commission hearings typically engage rights against selfincrimination or afford use immunity to any incriminating information compelled, ${ }^{5}$ while accountability programmes may require the provision of self incriminating information in order to participate and make no such guarantees of non-disclosure or use immunity. ${ }^{6}$

This issue comes to the fore as Nepal establishes transitional mechanisms to address past violations. The Nepalese truth commission is, in addition to fulfilling a traditional truth seeking function, responsible for making recommendations for

\footnotetext{
${ }^{3}$ A. Bisset, 'Principle 9: Guarantees for Persons Implicated' in F. Haldemann, P. Gaeta and T. Unger (eds), Commentary on the UN Principles to Combat Impunity (2016) (forthcoming).

${ }^{4}$ A. Bisset, Truth Commissions and Criminal Courts, (2012), 74-103.

${ }^{5}$ South Africa, Promotion of National Unity and Reconciliation Act 1995, s.31(3); Ghana, National Reconciliation Commission Act 2002, s.15(2); Kenya, Truth Justice and Reconciliation Commission Act 2008, s.24(3).

${ }^{6}$ See, Chega!, Report of the Commission for Reception, Truth and Reconciliation for East Timor, (2006), Part 9.
} 
amnesty. ${ }^{7}$ In order to be eligible for such a recommendation, it seems that the person concerned must make full disclosure of their involvement in past violations. ${ }^{8}$ However, the enacting domestic legislation offers no guidance on whether or how the due process rights of participants might be protected or how the information they disclose will be utilized.

This article explores the extent to which those who participate in truth commission administered accountability programmes are legally protected, with a particular focus on the privilege against self-incrimination. It will consider the programmes operated to date and examine the levels of protection typically afforded. It will examine international legal standards on the privilege against self-incrimination and question whether the procedures operated by accountability programmes can be reconciled with international norms in order to protect those who make self-incriminating disclosures within accountability initiatives. The article will demonstrate a lack of consistent practice in the safeguarding of individual rights within these programmes. It will argue that a failure to ensure individual rights against self-incrimination risks compromising the efficacy of the systems themselves and the contribution that they can make to long term peace and reconciliation in transitional states.

\section{Truth commissions, accountability initiatives and procedural protection}

\footnotetext{
${ }^{7}$ Ordinance on Investigation of Disappeared Persons, Truth and Reconciliation Commission, 14 March 2013, Ordinance No. 8 of 2012/2013, s.23.

${ }^{8}$ S. 23(5).
} 
Although truth commissions are not courts, their operation raises a range of due process related issues. They are routinely created with quasi-judicial powers ${ }^{9}$ to issue summonses and subpoenas, conduct search and seizure operations and require the delivery of statements under oath. It is common for commissions to publish the names of individuals and institutions considered responsible for past violations in their final reports. There is agreement that it is not necessary for commissions to adhere to the strict standards of criminal trials, with which due process is normally associated, because the consequences of being found responsible by a commission are much less severe than those of being found guilty in a court. ${ }^{10}$ However, it has been argued that where similar rights are implicated, due process standards 'provide a useful benchmark of fairness' for commissions. ${ }^{11}$ Internationally agreed principles evince a consensus that commissions should adhere to certain standards, such as notifying those implicated of the allegations against them, affording them a right to reply, ensuring the right against self-incrimination, corroborating implicating information before publicly naming individuals and making clear that published findings do not constitute judgments of legal or criminal guilt. ${ }^{12}$ Modern enacting legislation has typically stipulated that self-incriminating evidence obtained under truth commission

\footnotetext{
${ }^{9}$ M. Freeman, Truth Commissions and Procedural Fairness, (2006).

${ }^{10}$ UNHCHR, Rule of Law Tools for Post-Conflict States: Truth Commissions, (2006), 21.

${ }^{11}$ Freeman, supra note 9, 110; Report of the Special Rapporteur on the promotion of truth, justice, reparation and guarantees of non-recurrence, A/67/368, 13 September 2012, paras. 72-3.

${ }^{12}$ D. Orentlicher, Updated Set of Principles for the Protection and Promotion of Human Rights through Action to Combat Impunity, UN Doc. E/CN.4/2005/102/Add.1, 8 February 2005, Principle 9; E. González and H. Varney (eds.), Truth Seeking: Elements of Creating an Effective Truth Commission, (2013), 26; UNHCHR, supra note 10, 21-22.
} 
powers of compulsion cannot be used in subsequent criminal proceedings. ${ }^{13}$ Final reports document commission efforts to base findings on pre-determined standards of proof $^{14}$ and to adhere to standards of procedural fairness, despite the difficulties of locating implicated persons in order to notify them ${ }^{15}$ and afford them the right to reply, ${ }^{16}$ and the complexities of corroborating thousands of statements. ${ }^{17}$

Of late, truth commissions have not only been tasked with uncovering and recording the truth. Increasingly, they are called upon to administer accountability programmes and, within these, to exercise additional, sometimes adjudicative, functions. As well as traditional truth seeking, accountability programmes such as granting amnesty in exchange for truthful testimony, ${ }^{18}$ drawing up community service agreements between perpetrators and their communities ${ }^{19}$ and deciding on financial compensation arrangements for victims ${ }^{20}$ have all featured in recent truth commission mandates.

\footnotetext{
${ }^{13}$ South Africa, Promotion of National Unity and Reconciliation Act 1995, s. 31(3); Ghana, National Reconciliation Commission Act 2002, s. 15(2); An Act to Establish the Truth and Reconciliation Commission (TRC) of Liberia 2005, s. 30; Kenya, Truth, Justice and Reconciliation Act 2008, s. 24(3).

${ }^{14}$ Chega!, supra note 6, Part 2, paras. 34-5; Final Report of the Truth and Reconciliation Commission for Liberia (2009), Vol. 1, Section 2, Part C; TRC of South Africa Report, supra note 1, Vol. 1, Ch. 4; From Madness to Hope: The Twelve Year War in El Salvador: Report of the Commission on the Truth for El Salvador, UN Doc. S/25500 (1993), Ann.; Witness to Truth, supra note 2, Vol. 2, Ch. 2, para. 5. ${ }^{15}$ Report of the Truth, Justice and Reconciliation Commission, (2013), Vol. 1, Ch. 2 para. 61. See also Witness to Truth, ibid, Vol. 1, Ch. 5, 154-55; Report of the TRC for Liberia, ibid, Vol. II, 190.

${ }^{16}$ Chega!, supra note 6, Part 2, para. 34.

${ }^{17}$ Witness to Truth, supra note 2, Vol. 1, Ch. 5, 151.

${ }^{18}$ Promotion of National Unity and Reconciliation Act, 1995, Ch. Four.

${ }^{19}$ UNTAET Regulation 2001/10, ss. 22-32.

${ }^{20}$ Freeman, supra note 9, 35
} 
This represents an acknowledgement in transitional justice practice of the importance of implementing multi-faceted programmes, which address the range of victim and societal needs and interests. Studies show that national level initiatives, and in particular the need to ensure the accountability of low-level perpetrators, are as important to victims as international prosecutions of those most responsible for the most serious crimes. ${ }^{21}$ If future transitional programmes also encompass efforts to address lower-level responsibility it seems likely that, as has been the situation to date, truth commissions may be tasked with delivering those schemes. That being the case, it is important that truth commissions operate in accordance with internationally accepted standards of fairness in their administration of accountability programmes. Arguably, it is more important that such standards are adhered to in relation to accountability programmes because, as discussed above, the consequences that flow from them are often more significant than those which flow from simple truth seeking operations. Yet to date, adherence to standards of fairness has been less consistent and, in some cases, much less rigorous within accountability initiatives than it has been within truth commission proceedings.

\subsection{South Africa}

South Africa's truth for amnesty model remains the highest profile accountability initiative and has served to inform subsequent mechanisms. While it did not operate

\footnotetext{
${ }^{21}$ No Peace Without Justice, Closing the Gap: The Role of Non-Judicial Mechanisms in Addressing Impunity, (2010).
} 
without issue, ${ }^{22}$ the South African model was carefully constructed. The TRC's Amnesty Committee was tasked with granting amnesty to individuals who submitted timely applications making full disclosure of politically motivated acts involving a gross violation of human rights. ${ }^{23}$ The 1995 Act laid down a detailed procedure, outlining the process by which applications were to be considered and affording applicants rights to notification of hearings, to appear, to testify, to adduce evidence and to be informed, in writing, of the Committee's decision. ${ }^{24}$ A grant of amnesty extinguished all criminal and civil liability relating to the act. Any criminal conviction based upon the act was expunged from official records. ${ }^{25}$ For those who were not granted amnesty, and therefore remained liable to civil and criminal trial, incriminating information obtained by the Commission could not be used in prosecutorial investigations ${ }^{26}$ and was not admissible in any subsequent court proceedings. ${ }^{27}$ Where proceedings had been halted due to an amnesty application, and the application had not been successful, no adverse inference was to be drawn from the resumption of proceedings by the court concerned. ${ }^{28}$ The South African model therefore sought to deliver a high level of protection to those who applied for amnesty

\footnotetext{
${ }^{22}$ A. du Bois-Pedain, Transitional Amnesty in South Africa, (2007), 185; J. Sarkin, Carrots and Sticks: The TRC and the South African Amnesty Process, (2004), 127-34.

${ }^{23}$ S. 20(1).

${ }^{24}$ Ss. 19 and 21.

${ }^{25}$ S. 20(7).

${ }^{26}$ P. Gready, The Era of Transitional Justice: The Aftermath of the Truth and Reconciliation Commission in South Africa and Beyond, (2011), 102.

${ }^{27}$ S. 31(3).

${ }^{28} \mathrm{~S} .21(2)(b)$.
} 
and to maintain fairness in both amnesty proceedings and any subsequent action involving the same conduct.

\subsection{Timor Leste}

The Timorese Commission for Reception, Truth and Reconciliation (CAVR) provides another example of a commission that administered an accountability programme. The Timorese model displays a contrast in levels of protection between the operations of the Commission itself and those of the Community Reconciliation Process (CRP) that it administered. Prosecution was the central focus of the Timorese transitional justice programme. In order to maximize the possibilities for criminal justice, the Commission was under an obligation to refer human rights violations to the Office of the General Prosecutor (OGP), with recommendations for the prosecution of offences where appropriate. ${ }^{29}$ To protect the due process rights of those who appeared before the CAVR, safeguards were included in the commission's enacting legislation. Witnesses could be compelled to appear before the commission ${ }^{30}$ and to answer questions under oath, ${ }^{31}$ but they could not be compelled to give self-incriminating evidence or evidence that would incriminate a close relative. ${ }^{32}$ Those invited or compelled to appear had the right to legal representation ${ }^{33}$ and the commission's

\footnotetext{
${ }^{29}$ UNTAET Regulation No. 2001/10, s 3.1(c).

${ }^{30}$ S. 14.1(c).

${ }^{31}$ S. $14.1(\mathrm{~d})$.

${ }^{32}$ Ss.17.1 and .17.2.

${ }^{33}$ S. 18.
} 
search and seizure powers were to be exercised in accordance with a detailed procedure. ${ }^{34}$

A less stringent set of safeguards applied to the CAVR administered CRP. The CRP allowed perpetrators of minor offences to obtain immunity from prosecution ${ }^{35}$ by submitting a statement to the Commission, admitting responsibility for past crimes in a community hearing and undertaking an act of reconciliation. ${ }^{36}$ Initial statements made within the context of the CRP had to be forwarded to the OGP where it was decided whether the Prosecutor's jurisdiction would be exercised or whether the case could be dealt with through a CRP ${ }^{37}$ However, the CRP process was not regulated in the same way as disclosures made within the truth seeking proceedings. In particular, participants had no right to legal representation. Burgess notes that the CRP resulted in a situation where the OGP had access to all deponent statements on their involvement in past events, which they had made without legal advice. ${ }^{38}$ Although deponents were advised that statements could be used in prosecutions, they provided information in the belief that they would not be prosecuted, but reintegrated through CRP.

\footnotetext{
${ }^{34}$ S. 15.

${ }^{35}$ Chega!, supra note 4, paras. 3-4.

${ }^{36}$ Ibid, Part 9.2, para. 10.

${ }^{37}$ Ibid, para. 10.

${ }^{38}$ P. Burgess, 'East Timor's Community Reconciliation Process', in N. Roht-Arriaza and J. Mariezcurrena (eds.), Transitional Justice in the Twenty-First Century: Beyond Truth versus Justice,
} (2006), 176-205, 195-196. 
In practice, 85 cases were retained by the OGP. 32 were adjourned mid-hearing as credible evidence of involvement in a serious crime came to light, rendering them outside the mandate of the CAVR ${ }^{39}$ Limited resources meant that these cases could not be investigated. ${ }^{40}$ However, had the capacity been available, prosecutions might have been initiated on the basis of self-incriminating information provided by the accused in the belief that disclosure was necessary to participate in a reintegration and reconciliation process. That evidence would have been provided without legal advice or representation. It seems somewhat incongruous that participation in truth commission hearings should attract a well thought out series of safeguards, while the reintegration process administered by the same body should entail virtually none and have the potential to create situations where due process rights might be seriously undermined.

\subsection{Kenya}

In 2006, Burgess argued that the inadequacies of the Timorese CRP should be remedied in any similar, future programmes. ${ }^{41}$ Kenya's 2008 Truth, Justice and Reconciliation Commission (TJRC) Act seemed to move in this direction. Although the TJRC ultimately decided not to operate the amnesty scheme laid down in its enacting legislation, ${ }^{42}$ the Act provided protections for those who might have taken

\footnotetext{
${ }^{39}$ Chega!, supra note 4, Part 9, para.102.

${ }^{40}$ Ibid, para. 169.

${ }^{41}$ Burgess, supra note 38 , at 196.

${ }^{42}$ TJRC Report, supra note 15, Vol. 1, Ch. 2, 71.
} 
part. The Act gave the TJRC authority to receive applications and make recommendations for amnesty for acts or omissions not amounting to international crimes or gross violations of human rights. ${ }^{43}$ Where amnesty hearings were convened, the applicant had rights to be notified, ${ }^{44}$ to be present and to testify, ${ }^{45}$ and to have legal representation. ${ }^{46}$ Any ongoing civil or criminal proceedings could be suspended pending an amnesty decision ${ }^{47}$ and applicants were to be notified in writing and with reasons of any refusal. ${ }^{48}$ Any confession or admission submitted in relation to the amnesty application was prohibited from use in subsequent court proceedings, regardless of the amnesty outcome. ${ }^{49}$

In many ways, the 2008 Kenyan Act mirrors the protections offered by the earlier South African TRC, although it does not prevent the drawing of adverse inferences where proceedings have been halted due to an amnesty application and then resumed. However, the Truth, Justice and Reconciliation (Hearing Procedure) Rules 2011 enable the TJRC to recommend prosecutions and require it to support the recommendation with evidence showing that there are reasonable grounds to believe that a crime was committed by that person. ${ }^{50}$ There is no apparent bar on the use of admissions or confessions submitted in respect of amnesty applications for this

\footnotetext{
${ }^{43}$ S. 34(1)-(3).

${ }^{44}$ S. 36(5)(a).

${ }^{45}$ S. 36(5)(b).

${ }^{46}$ S. 28.

${ }^{47}$ S.36(7) and (8).

${ }^{48}$ S. 40.

${ }^{49}$ S.36(9)(c).

${ }^{50}$ The Truth, Justice and Reconciliation (Hearing Procedure) Rules 2011, s. 19(2).
} 
purpose. Although admissions could not be used as direct evidence in court against the person who made the statement, they might nevertheless be passed to prosecutorial bodies and used to further criminal investigations. A situation arises, albeit hypothetical in this instance, where individuals disclose involvement in past crimes in order to be eligible for consideration under one transitional process, presumably unaware that it might be passed to prosecuting bodies and used to initiate criminal investigations.

\subsection{Nepal}

More unsatisfactory is the Nepalese Commission on Investigation of Disappeared Persons, Truth and Reconciliation Act, 2071 (2014), ${ }^{51}$ under which the truth commission will fulfill a truth seeking function, as well as make recommendations for amnesty $^{52}$ and for prosecutions before a future Special Court. ${ }^{53}$ The recommendations may therefore have significant legal impact, yet potential participants in the amnesty process do not appear to be afforded any procedural protections.

\footnotetext{
51 On the original Nepali model see International Commission of Jurists, Authority without Accountability: The Struggle for Justice in Nepal, (2013); OHCHR, Comments on the Nepal 'Commission on Investigation of Disappeared Persons, Truth and Reconciliation Ordinance' - 2069 (2013)' (2013).

${ }^{52}$ Controversially, the 2014 Act, s.26, maintains the possibility of amnesty for gross violations of human rights. See International Commission of Jurists, Justice Denied: The 2014 Commission on Investigation of Disappeared Persons, Truth and Reconciliation Act, (2014).

${ }^{53}$ Ss. 25 and 29.
} 
Amnesty applicants are required to make full, written disclosure of their past activities, including an acceptance of having committed gross violations of human rights, repentance and apology for those actions and a commitment not to repeat them. ${ }^{54}$ The Act discusses 'investigations' related to amnesty applications, which may include ascertaining the views of victims. ${ }^{55}$ It is not clear whether these 'investigations' might include hearings, but if they do, there is no provision for notification of the applicant or of any right to be present, to reply to accusations or to legal representation. There is no prohibition on the use of amnesty application disclosures in any subsequent proceedings against the applicant or on the sharing of these disclosures with other institutions, including prosecutorial bodies. The opposite appears true. The Act makes provision for the Commission's information to be available to other bodies to which it might be useful and for the Commission to cooperate with any other agency established by the Government, presumably including those pursuing criminal investigations. The recommendatory roles relating to amnesty and prosecutions seem interlinked as the Act provides that where amnesty is not granted, the process for filing a criminal case should be pursued. ${ }^{56}$ It is possible that the Commission will use the powers designated under s.40 to frame rules to develop a series of procedural safeguards for potential applicants. However, as it stands, the Act falls below the standards to which commissions are internationally expected to operate in accordance with.

\subsection{Conclusion}

\footnotetext{
${ }^{54}$ S. 26(3) and (4).

${ }^{55}$ S. 26(5).

${ }^{56}$ S. 26(9).
} 
Thus, the truth commission accountability programmes established to date entail varying levels of protection for those who participate in them, from the robust safeguarding of individual rights within the South African model to the seeming absence of protection within the Nepalese Act. The potential use of self-incriminating testimony is of particular concern due to the far-reaching consequences its use in subsequent legal proceedings might pose.

\section{Accountability initiatives and the privilege against self-incrimination}

\subsection{The privilege against self-incrimination}

It might be assumed that the use in subsequent legal proceedings of self-incriminating information disclosed during transitional accountability initiatives would violate the privilege against self-incrimination and therefore the right to a fair trial. There is a wealth of legal provisions on the privilege against self-incrimination in criminal proceedings. It is well established in international law as a fundamental facet of the right to a fair trial and enshrined in numerous international statutes and conventions, ${ }^{57}$

\footnotetext{
${ }^{57}$ International Covenant on Civil and Political Rights (ICCPR), 16 December 1966, 999 UNTS 171, Art. 14(3)(g); American Convention on Human Rights (ACHR), 22 November 1969, 1144 UNTS 123, Art. 8(2)(7). Neither the African Charter on Human and Peoples' Rights nor the European Convention on Human Rights explicitly mention the right against self-incrimination. In the ECHR context, it has been recognized in the jurisprudence on Art. 6. See, John Murray v. UK, Decision of 8 February 1996, [1996-I] ECHR 49 and Saunders v. UK, Decision of 17 December 1996, [1996] ECHR 65, at para. 68.
} 
as well as in many national legal systems. ${ }^{58}$ It is protected within the Statutes for the ad hoc tribunals, ${ }^{59}$ in those of some of the hybrid courts ${ }^{60}$ and at the investigation and trial stages within the Statute of the International Criminal Court (ICC). ${ }^{61}$

Scholarship evinces some consensus that the privilege serves to ensure that a suspect cannot be required to provide authorities with information that might be used against him in a criminal trial. ${ }^{62}$ It "presupposes that the prosecution in a criminal case seek to prove their case against the accused without resort to evidence obtained through methods of coercion or oppression in defiance of the will of the accused'. ${ }^{63}$ Internationally, there is agreement that the privilege offers protection at two crucial stages; endowing a defendant with a right not to give evidence at trial and a suspect with a right to silence in pre-trial criminal investigations. ${ }^{64}$

${ }^{58}$ M.C. Bassiouni, "Human Rights in the Context of Criminal Justice: Identifying International Procedural Protections in National Constitutions", (1992-3) 3 Duke Journal of International and Comparative Law 235, 265, n.138.

${ }^{59}$ Art. 21(4)(g) ICTY St; Art. 20(4)(g) ICTR St.

${ }^{60}$ Statute of the Special Court for Sierra Leone, appended to the Report of the Secretary-General on the Establishment of a Special Court for Sierra Leone, S/2000/915, 4 October 2000, Art. 17(4)(g); Law on the Establishment of Extraordinary Chambers in the Courts of Cambodia for the Prosecution of Crimes Committed during the Period of Democratic Kampuchea, Art. 35(g).

${ }^{61}$ Arts. 55(1)(a) and 67(1)(g).

${ }^{62}$ M. Redmayne, 'Rethinking the Privilege Against Self-Incrimination', (2007) 27 Oxford Journal of Legal Studies 209. See also P. McInerney, 'The Privilege Against Self-Incrimination from Early Origins to Judges' Rules: Challenging the "Orthodox View"', [2014] International Journal of Evidence and Proof 101.

${ }^{63}$ Saunders, supra note 57, para. 68. See also Redmayne, ibid, at 225.

${ }^{64}$ McInerney, supra note 62. 
Although there appears to be increasing global acceptance of, and respect for such rights, there is no uniform international practice in relation to them. ${ }^{65}$ Different jurisdictions recognise variations of the privilege at different junctures of the criminal process ${ }^{66}$ and interpret its requirements differently. ${ }^{67}$ Even within international human rights instruments there is no consensus on the stage at which the privilege is engaged. Some instruments refer to post-charge protection, ${ }^{68}$ while others simply consider the privilege applicable when a criminal 'accusation' is made. ${ }^{69}$ This confusion is argued to flow from the lack of an underpinning rationale justifying the privilege, ${ }^{70}$ with it having been rationalised on autonomy, ${ }^{71}$ choice ${ }^{72}$ and privacy grounds, ${ }^{73}$ among others.

${ }^{65}$ C. Bradley (ed.), Criminal Procedure: A Worldwide Study, (1999).

${ }^{66}$ Ibid.

${ }^{67}$ See M. Berger, 'Compelled Self-Reporting and the Principle Against Compelled Self-Incrimination: Some Comparative Perspectives', 2006 European Human Rights Law Review 25.

${ }^{68}$ ICCPR, Art. 14(3)(g). See also Canadian Charter of Rights and Freedoms, s. 11(c).

${ }^{69}$ ACHR, Art. 8(2)(7).

${ }^{70}$ D. Dolinko, 'Is there a Rationale for the Privilege Against Self-Incrimination?', (1986) 33 UCLA Law Review 1063; R. Allen, ‘Theorizing About Self-Incrimination', (2008) 30 Cardozo Law Review 751.

${ }^{71}$ Redmayne, supra note 62, at 218-25.

${ }^{72}$ B. M. Dann, 'The Fifth Amendment Privilege Against Self-Incrimination: Extorting Physical Evidence from a Suspect', (1970) 43 Southern California Law Review 597; W. J. Stuntz, 'SelfIncrimination and Excuse', (1988) 88 Columbia Law Review 1227.

${ }^{73}$ A. E. Taslitz, 'Confessing in the Human Voice: A Defense of the Privilege Against SelfIncrimination', (2008) 7 Cardozo Public Law, Policy and Ethics Journal 121. 
The lack of clarity on the nature and scope of the privilege makes it difficult to ascertain whether it protects individuals within accountability schemes. The following sections draw on national and regional jurisprudence in an effort to develop a broad understanding of whether the privilege is engaged in relation to those offering testimony as part of national accountability initiatives and, if so, the nature of the protection it might offer.

\subsection{Applicability of the Privilege}

It is first necessary to assess the applicability of the privilege in proceedings that are not strictly part of, but may have links to, the formal criminal process. International and regional attention, at the UN Human Rights Committee, ${ }^{74}$ Inter-American Court ${ }^{75}$ and African Commission on Human and Peoples Rights, ${ }^{76}$ has primarily focused on whether the use of physical force and verbal abuse to obtain confessions amount to a violation. The situation at issue here is more akin to some of those that have been

\footnotetext{
${ }^{74}$ Human Rights Committee, ICCPR A/52/40 vol. I (1997), paras. 241-2, 357; ICCPR A/56/40 vol. I (2001) 59, 70; ICCPR A/59/40 vol. I (2003) 15; ICCPR A/60/40 vol I. (2004), 25; ICCPR A/60/40 vol. I (2005), 70.

${ }^{75}$ Cabrera Garcia and Montiel Flores v. Mexico, Inter-American Court of Human Rights, Preliminary Objection, Merits, Reparations and Costs, 26 November 2010; Maritza Urrutia v. Guatemala, InterAmerican Court of Human Rights, Merits, Reparations and Costs, 27 November 2003.

${ }^{76}$ Egyptian Initiative for Personal Rights and Interights v. Arab Republic of Egypt, African Commission on Human and Peoples’ Rights, Comm. No. 368/09 (2014); Malawi African Association and Others v. Mauritania, African Commission on Human and Peoples’ Rights, Comm. Nos. 54/91, 61/91, 96/93, 98/93, 164/97, 196/97, 210/98 (2000).
} 
considered by the European Court of Human Rights (ECtHR), making its jurisprudence most pertinent to this evaluation.

Although the privilege is not expressly included within the ECHR, the Court has inferred it from human rights instruments and the guarantee of a fair trial in Art 6(1). ${ }^{77}$ The ECtHR's judgments reveal a distinction between the right to silence, when an accused fails to answer questions or to testify, and the privilege against selfincrimination, which involves the threat of coercion to obtain information from an accused. ${ }^{78}$ For the ECtHR, the privilege lies at the heart of a fair procedure by supporting the presumption of innocence and contributing to the avoidance of miscarriages of justice. ${ }^{79}$ The cases considered primarily fall into two camps: those relating to the use of compulsion for the purpose of obtaining information which might incriminate the person concerned in pending criminal proceedings against them $^{80}$ and those which relate to the use of incriminating information compulsorily obtained outside the context of criminal proceedings in a subsequent prosecution. ${ }^{81}$

\footnotetext{
${ }^{77}$ Murray, supra note 57; Saunders, supra note 57; Heaney and McGuinness v. Ireland, Decision of 21 December 2000, [2000] ECHR (Ser. A) 684; Weh v. Austria, Decision of 8 April 2004, (2005) 40 EHRR 37; Luca v. Italy, Decision of 27 February 2001, (2003) 36 EHRR 46; JB v. Switzerland, Decision of 3 May 2001, [2001] Criminal Law Review 748.

${ }^{78}$ A. Ashworth, 'Self-Incrimination in European Human Rights Law - A Pregnant Pragmatism', (2008) 30 Cardozo Law Review 751, at 754.

${ }^{79}$ Funke v. France, Decision of 25 February 1993, (1993) 16 EHRR 297; Murray, supra note 57; Saunders, supra note 57. See too J. Jackson, 'Reconceptualizing the Right of Silence as a Fair Trial Standard', (2009) 58 ICLQ 835, at 841-849.

${ }^{80}$ Funke, ibid; Heaney and McGuinness, supra note 77.

${ }^{81}$ Saunders, supra note 57; I.J.L and others v. UK, Decision of 19 September 2000, (2001) 33 EHRR 11.
} 
Beyond this categorization, the Court has deemed the privilege to apply across a range of subtler scenarios. Case law shows that the privilege is engaged not only (1) at trial ${ }^{82}$ and (2) during the pre-trial phase. ${ }^{83}$ It also applies (3) in procedures deemed to fall within the autonomous meaning of a criminal charge, including administrative investigations or disciplinary procedures, ${ }^{84}$ (4) where evidence is obtained under compulsion in non-punitive procedures but is later used in criminal proceedings against the person concerned; ${ }^{85}$ and (5) where a person is penalized for failure to comply with a duty to provide information. ${ }^{86}$ The Court has therefore taken an expansive and protective approach in relation to the privilege.

However, the convolution of the case law presents challenges in ascertaining its applicability to accountability schemes. Accountability schemes are not analogous to trial or pre-trial proceedings as they do not form part of the formal criminal process. Neither is it clear that the case law on procedures that fall within the autonomous meaning of a criminal charge would encompass accountability schemes, although it has been held that a variety of proceedings including taxation, ${ }^{87}$ prison discipline ${ }^{88}$

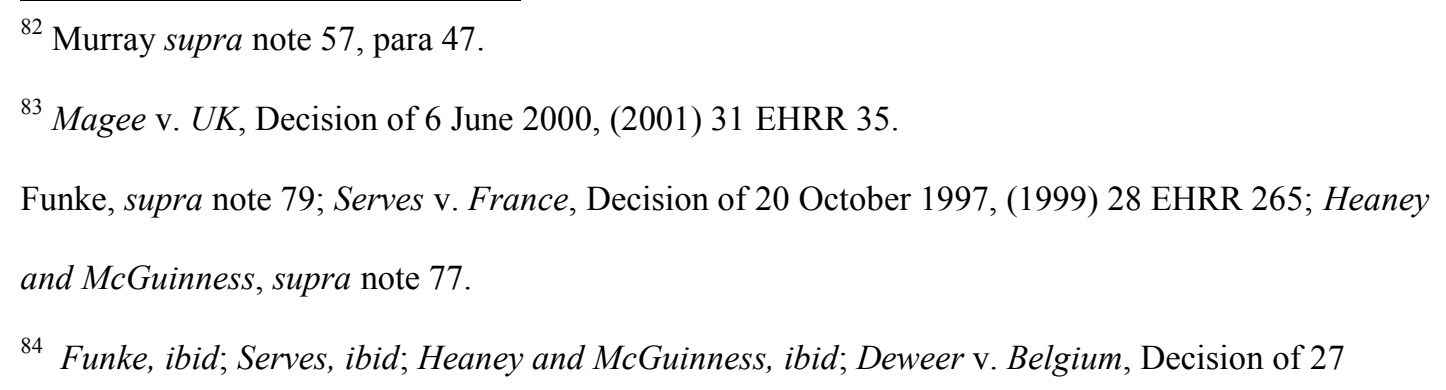


and minor traffic offences ${ }^{89}$ can fall within this category. In determining whether situations fall within the autonomous meaning of a criminal charge, the Court examines, alternatively and not cumulatively, ${ }^{90}$ the classification of the offence under domestic law, the nature of the offence and the severity of the penalty. ${ }^{91}$ Accountability schemes are concerned with actions that fall within the confines of the criminal law. However, no offence will actually have been charged or penalty imposed when an individual decides to participate and, although not required in the Court's jurisprudence, ${ }^{92}$ the domestic law creating the scheme will not belong under the criminal branch, even if it is linked indirectly to it. At the same time, the Court has dismissed the suggestion that the privilege is not at issue simply because there are no substantive proceedings underway in which information could be used. ${ }^{93}$ It has stressed that it is not uncommon for procedures to combine varying elements and that it may not be possible to separate those parts of the proceedings which determine a 'criminal charge' from those parts that do not. ${ }^{94}$

It is similarly unclear whether the second criteria that 'the offence in question is by its nature to be regarded as criminal ${ }^{95}$ would be met. Although accountability schemes

\footnotetext{
${ }^{89}$ Ozturk v. Germany, Decision of 21 February 1984, (1984) 6 EHRR 409.

${ }^{90}$ Janosevic, supra note 87, para. 65-7.

${ }^{91}$ Engel and others v. Netherlands, Decision of 21 November 1975, (1976) 1 EHRR 647; Ezeh and Connors, supra note 88, para 82; Jusilla, supra note 84.

92 Janosevic, supra note 87.

${ }^{93}$ See Marttinen v. Finland, Decision of 21 April 2009, (2010) 50 EHRR 46, para. 63-4, re. when an individual might be considered 'charged' for the purposes of the privilege under Art. $6(1)$.

${ }^{94}$ Jusilla, supra note 84, para. 45.

${ }^{95}$ Ezeh and Connors, supra note 88, para 86; Jusilla, ibid, para. 31.
} 
are concerned with criminal conduct, their purpose may be considered non-punitive in that they are tasked with granting amnesties or facilitating reintegration agreements. On the other hand, if deemed ineligible for the scheme, criminal proceedings and punitive sanctions may follow. The final criteria that the 'offence renders the person liable to a penalty which by its nature and degree of severity belongs in the general criminal sphere' does seem to be met as in the event that individuals are deemed ineligible for participation in accountability schemes they become liable to prosecution and, if convicted, attendant penalties. ${ }^{96}$ The Court has also made clear that where it is difficult to reach a clear conclusion based on the separate analysis of each criterion, a cumulative approach may be necessary. ${ }^{97}$ Such an approach, coupled with the Court's determination to provide real, rather than illusory protection, ${ }^{98}$ may support the contention that accountability schemes can be encompassed within procedures falling within the autonomous meaning of a criminal charge. Yet, it remains difficult to state definitively that accountability schemes fall under this category.

It might be considered that accountability schemes are more likely to come within the fourth scenario. This is illustrated in Saunders, where the applicant complied with a directive that he answer potentially self-incriminating questions under the threat of contempt during an administrative procedure, and his responses were subsequently used in his distinct but related criminal prosecution for breach of the Companies Act

\footnotetext{
${ }^{96}$ Ibid.

${ }^{97}$ Jusilla, supra note 84, para. 31.

98 Jusilla, ibid, para. 30.
} 
1985. The Court found a violation of his right to a fair trial on the basis of the use of the compelled statements at trial; the issue on which the alleged violation was based.

The Court did not consider whether the privilege was applicable in the administrative proceedings, but noted that the function of these were investigative and nonadjudicative, with a purpose of recording facts which might subsequently be used as the basis for action by other competent authorities. The Court noted that a requirement that preparatory investigations should be subject to the guarantees set forth in Article 6(1) would unduly hamper the effective regulation in the public interest of complex financial and commercial activities. ${ }^{99}$ In relation to accountability schemes, this may suggest that the privilege is not applicable during accountability proceedings themselves as these may be considered investigative and nonadjudicative. Information is sought not for the purpose of prosecution, but to contribute to national truth seeking and to determine eligibility for an accountability scheme. Nonetheless, the Saunders decision appears to suggest that as long as compulsion can be demonstrated, ${ }^{100}$ the privilege might prevent the use of incriminating statements obtained in accountability schemes in any subsequent trial for the same conduct.

Finally, the ECtHR has examined cases where a person is penalized for failure to comply with a duty to provide information. ${ }^{101}$ An issue of preliminary importance in these cases in that there must be a sufficiently proximate link between the obligation

\footnotetext{
${ }^{99}$ Saunders, supra note 57, para 67; Fayed v. UK, Decision of 21 September 1994, (1994) 18 EHRR 393, para. 61-62.

${ }^{100}$ See section 3.3.

${ }^{101}$ Weh, supra note 77.
} 
to disclose information and the possibility of criminal proceedings; the possibility must be more than remote and hypothetical. ${ }^{102}$ The Court has distinguished situations where criminal proceedings were pending or anticipated ${ }^{103}$ from those where they were not. In the latter situation it has frequently been found that the privilege is not engaged. ${ }^{104}$ Yet such decisions are not always unanimously reached and judicial division has emerged on the point at which criminal proceedings are envisaged. ${ }^{105}$ Accountability schemes cannot easily be considered equivalent to such a scenario as there is no duty, perhaps other than a moral one, to participate and disclose information. The Court's reasoning in such cases is nevertheless interesting as it again demonstrates a desire to provide protection where domestic disclosure laws extinguish "the very essence of the ...rights to silence and against selfincrimination'. 106

This contextual approach to decision making on applicability, coupled with the inherent judicial division, ${ }^{107}$ is not unique to the ECtHR. Canadian courts have also stressed the importance of context in cases concerning the privilege, adopting a case-

\footnotetext{
${ }^{102}$ Weh, ibid, para. 53-6.

${ }^{103}$ Funke, supra note 79; Heaney and McGuinness, supra note 77; Marttinen, supra note 93.

${ }^{104}$ Abas v. Netherlands, Decision of 26 February 1997, [1997] EHRLR 418; IJL, GMR and AKP v.

UK, Decision of 19 September 2000, (2001) EHRR 11; Allen v. UK, Decision of 10 September 2002,

(2002) 35 EHRR CD289; Van Weerelt v. Netherlands, Decision of 16 June 2015.

${ }^{105}$ Weh, supra note 77, Dissenting Opinion of Judges Lorenzen, Levits and Hajiyev, para. 1. On US

divisions see Marchetti v. U.S. 390 U.S. 39, 53 (1968); Grosso v. U.S. 390 US 62 (1968).

${ }^{106}$ Marttinen, supra note 93, para 75.

${ }^{107}$ Saunders, supra note 57; Weh, supra note 77.
} 
by-case analysis of the specific circumstances. ${ }^{108}$ In US jurisprudence, it has been held that Fifth Amendment protections apply only where the individual is asked to give testimony that may expose him to criminal charge. ${ }^{109}$ 'The central standard for the privilege's application is whether the [person concerned] is confronted by substantial and "real," and not merely trifling or imaginary, hazards of incrimination'. ${ }^{110}$ Again, this has resulted in a line of jurisprudence in which various cases have fallen on different sides of the threshold. ${ }^{111}$

While case-by-case analysis seems logical, it creates difficulty in ascertaining whether the privilege protects disclosures made within accountability schemes. None of the scenarios considered before national or regional courts replicate exactly the scenario present in accountability schemes. Yet, a general theme across relevant jurisprudence seems to be the need for some form of connection between disclosures and criminal proceedings, whether that is explicit as in trial and pre-trial proceedings or implicit where, for example, on consideration of the facts, Article 6 under its criminal head is deemed to apply to administrative proceedings. Simply because criminal proceedings are unlikely to be pending or directly anticipated at the time of disclosure does not rule out the applicability of the privilege in relation to accountability schemes. The

\footnotetext{
${ }^{108}$ R. v. Fitzpatrick, [1995] 4 S.C.R. 154, per La Forest J. at para. 125; R. v. S. (R.J.), [1995] 1 S.C.R. 451, per Iocabucci, J. at paras. 107-8.

${ }^{109}$ Reg. v. Boyes, 1 B. \& S. 311, 330; Brown v. Walker, 161 U.S. 591, 599; Rogers v. United States, 340 U.S. 367,374 .

${ }^{110}$ Marchetti, supra note 105.

${ }^{111}$ R. J. Allen and K. M. Mace, 'The Self-Incrimination Clause Explained and its Future Predicted', (2004) 94 Journal of Criminal Law and Criminology 243, 256-9.
} 
ECtHR has dismissed such arguments across the categories of cases considered, preferring instead to afford protection where, on a contextual consideration of all the facts, it considers it necessary.

In accountability schemes, the system requiring disclosure may only be potentially and indirectly linked to criminal proceedings, yet the threat of prosecution remains present if disclosure is not forthcoming and that threat provides the impetus for disclosure. The dangers of assuming a clear distinction between criminal and noncriminal inquiries have been warned against. ${ }^{112}$ Choo notes that it may 'too readily be overlooked that, despite appearances, an individual subject to a regulatory procedure may actually be "in peril" of a criminal prosecution in respect of an offence to which the information required may be relevant'. ${ }^{113}$ Thus an argument can be made that the integral place of prosecution within accountability schemes means that those who participate within them are in fact 'in peril' of prosecution and that the privilege should therefore be considered applicable.

\subsection{Compulsion}

Even if it is accepted that the privilege is applicable in the context of accountability schemes, in order for the privilege to provide protection, it must also be established

\footnotetext{
${ }^{112}$ S. Sedley, 'Wringing Out the Fault - Self-Incrimination in the Twenty-First Century', (2001) 52 Northern Ireland Quarterly Review 107,123.

${ }^{113}$ A. L-T Choo, The Privilege Against Self-Incrimination and Criminal Justice, (2013), 32.
} 
that the testimony is 'compelled'. The UN Human Rights Committee has considered that direct or indirect physical or psychological pressure comes within the scope of the privilege. ${ }^{114}$ On the other hand, the Inter-American Court of Human Rights has held that being urged to tell the truth does not amount to compulsion. ${ }^{115}$

For the ECtHR, what is of interest is 'improper compulsion' and whether the degree of compulsion imposed on the accused destroyed the very essence of the privilege and the right to remain silent. ${ }^{116}$ Thus, not every measure employed to encourage individuals to offer information that might be used in criminal proceedings, will be considered to amount to improper compulsion. ${ }^{117}$ Context is important, with decisions, again, reached on a case-by-case basis. Compulsion has been held to be improper where the state has used the threat of criminal punishment to compel the provision of potentially self-incriminating evidence in criminal cases. ${ }^{118}$ It is similarly improper for the state to resort to subterfuge in order to obtain self-incriminating information that an individual refused to give at interview and to use that information at trial. ${ }^{119}$ The use in criminal proceedings of statements made under the threat of

\footnotetext{
${ }^{114}$ Berry v. Jamaica, Communication No. 330/1988, U.N. Doc. CCPR/C/50/D/330/1988 (1994), para. 11.7 .

${ }^{115}$ Castillo Petruzzi and others v. Peru, Merits, Reparations and Costs, 30 May 1999, para. 167-8. ${ }^{116}$ See Heaney and McGuiness, supra note 77, paras. 48 and 55; Funke, supra note 79, para. 44; Murray, supra note 57, para. 49.

${ }^{117}$ Allen v. UK, supra note 104.

${ }^{118}$ Heaney v. Ireland [1994] 3 IR 593; Quinn v. Ireland, Decision of 21 December 2000, (2001) 33

EHRR 264; Funke, supra note 79.

${ }^{119}$ Allan v. UK, Decision of 5 November 2002, (2003) 36 EHRR 12.
} 
imprisonment in a compelled reporting system amounts to a violation, ${ }^{120}$ but the use of compulsory powers to require individuals to provide information relating to financial or company affairs does not. ${ }^{121}$ Neither do identity disclosure requirements under domestic traffic laws violate the privilege. ${ }^{122}$ Similarly, as long as procedural self-incrimination protections are in place, it is permissible for adverse inferences to be drawn from silence. ${ }^{123}$ Yet while it is clear that for the Court the privilege is only engaged where the compulsion is deemed improper, it is not altogether clear where the line between proper and improper is drawn.

US courts apply an objective test for compulsion under the Fifth Amendment, which asks whether 'considering the totality of the circumstances, the free will of the witness was overborne'. ${ }^{124}$ This too has given rise to case-by-case contextual analysis of whether governmental action has exceeded the threshold for the compulsion necessary for a Fifth Amendment violation. ${ }^{125}$ The US courts have produced a list of acceptable and unacceptable actions, locating types of pressure along their perception of the proper continuum. ${ }^{126}$

\footnotetext{
${ }^{120}$ Saunders, supra note 57.

${ }^{121}$ Allen, supra note 104 . Nor do laws requiring individuals to disclose personal details to police under threat of a fine violate the privilege. See Vasileva v. Denmark, Decision of 25 September 2003, (2005) 40 EHRR 27.

${ }^{122}$ Weh, supra note 77; O'Halloran and Francis v. UK, Decision of 29 June 2007, (2007) 46 EHRR

21.

${ }^{123}$ Condron v. United Kingdom, Decision of 2 May 2000, (2001) 31 EHRR. 1

${ }^{124}$ Rogers v. Richmond, 365 US 534, 544 (1961); US v. Washington, 431 US 181, 188 (1977).

${ }^{125}$ P. Arenella, 'Schmerber and the Privilege against Self-Incrimination: A Reappraisal', (1982) 20 American Criminal Law Review 31, 32; Allen and Mace, supra note 111, 250-6.

${ }^{126}$ Ibid, 256.
} 
Canadian jurisprudence on compulsion has been described as "haphazard". ${ }^{127}$ The Supreme Court has stated that, 'any state action that coerces an individual to furnish evidence against him- or herself in a proceeding in which the individual and the state are adversaries violates the principle against self-incrimination. Coercion...means the denial of free and informed consent'. ${ }^{128}$ This has been consistently interpreted as meaning that all statements made where an individual is obliged by law to give information are, per se, compelled. However, the case law is less consistent in cases where the voluntariness of disclosure has been in question, with contextual analysis of whether the individual's will was, in all the circumstances, overborne again resulting in cases falling either side of the acceptable/unacceptable threshold. ${ }^{129}$

If the privilege is to provide protection for those participating within accountability schemes, it must be established that disclosures are 'compelled'. From one perspective, self-incriminating testimony given in an accountability programme may not be considered to amount to compulsion. Participation is, in theory, voluntary and many decide not to apply. ${ }^{130}$ The disclosure element of accountability schemes might

${ }^{127}$ L. Dufraimont, 'The Patchwork Principle against Self-Incrimination under the Charter', (2012) 57 Supreme Court Law Review 241, 262.

${ }^{128}$ R. v. Jones, [1994] S.C.J. No. 42, [1994] 2 S.C.R. 229, para. 29, Lamer C.J.C. dissenting; $R$. v. Brown, [2002] S.C.J. No. 35, [2002] 2 S.C.R. 185, para. 92.

${ }^{129}$ Dufraimont, supra note 127.

${ }^{130}$ H. Varney, 'The Malan Trial (South Africa)', Presentation to International Centre for Transitional Justice, Domestic Prosecutions and Transitional Justice Conference, 16-19 May 2005, Magaliesburg, South Africa; J. Rauch, Police Transformation and the South African TRC, Centre for the Study of Violence and Reconciliation, (2004). 
be argued to be equivalent to being urged to tell the truth, which for the InterAmerican Court cannot amount to compulsion unless accompanied by threat of punishment for non-disclosure or by a requirement to testify under oath. ${ }^{131}$

For the ECtHR, decisions to participate in alternatives to criminal proceedings cannot be considered voluntary where those decisions are 'tainted by constraint'. ${ }^{132}$ Unless decisions are conscious, voluntary and free from duress or false promises ${ }^{133}$ fair trial protections continue to apply and cannot be considered waived. In the context of accountability schemes, it might be argued that the 'decision' to participate is not voluntary but 'tainted by constraint' due to the consequences that can, indeed should, flow from non-participation. For example, in South Africa, those who did not apply for amnesty and disclose involvement in past violations remained liable to civil suit and criminal prosecution. That will also be the case under the Nepali scheme. In Timor Leste, those who did not apply for CRP and disclose past wrongdoing risked prosecution as well as ostracization in a society in which community is central.

Potential participants are faced with a difficult, perhaps 'constrained', choice. ${ }^{134}$ Individuals must decide whether to participate, disclose and risk being denied amnesty and subsequently prosecuted or decide not to participate and risk prosecution if involvement in past crimes subsequently comes to light. There may not be a legal obligation to participate in the first instance and no direct legal penalties for failure to

\footnotetext{
${ }^{131}$ Berry, supra note 114, para. 167.

${ }^{132}$ Deweer, supra note 84.

${ }^{133}$ Natsvlishvili v. Georgia, Decision of 29 April 2014, para 97.

${ }^{134}$ Redmayne, supra note 62, 221-4.
} 
offer incriminating information, but the potential risks of not participating and testifying seem too great to ignore. Thus, the threat of the consequences that may flow from non-participation 'compel' individuals to participate in accountability schemes. It is not compulsion in the traditional sense of being physically forced or legally obliged to offer information. However, the pressure exerted by the state upon individual decision-making through the legislative model of truth for amnesty versus potential prosecution arguably injects an element of compulsion into accountability programmes. It can be argued that compulsion should be understood broadly in this context in order to encompass the disclosures made by those who participate in accountability schemes. Moreover, without affording such protection the aims of accountability schemes may be thwarted as those upon whose participation they depend may be inhibited from offering testimony where they fear that their disclosures may subsequently be used against them.

\subsection{The scope of the privilege}

Even if it can be argued that the privilege is engaged and that compulsion can be understood broadly to encompass the situation here, it remains uncertain whether the privilege protects individuals from the use against them of self-incriminating disclosures made within accountability schemes in subsequent criminal proceedings. The scope of the privilege is contested. International law, generally, takes a generous approach. The ICTY has been described as 'over-protective' ${ }^{135}$ in its approach,

\footnotetext{
${ }^{135}$ G. Sluiter and A. Zahar, International Criminal Law, (2008), 305.
} 
interpreting the privilege broadly ${ }^{136}$ and excluding evidence where it considers that the right has not been adequately protected. ${ }^{137}$ The ICC Statute takes an expansive approach, not only protecting the accused against self-incrimination, but enabling the Court to provide assurances to witnesses who might provide incriminating evidence. ${ }^{138}$ The Special Court for Sierra Leone also emphasized the importance of the privilege in its jurisprudence. ${ }^{139}$

At the same time, it is clear that the privilege is not absolute and may be subject to limitations. The ECtHR's jurisprudence on limitations and exceptions to the privilege is not consistent and a range of factors, including public interest, have been examined in making determinations. In early case law, the Court rejected arguments that limitation was justified in the public interest, ${ }^{140}$ stating that both the fairness requirements of Article 6 generally and the privilege itself should 'apply to all criminal proceedings in respect of all types of criminal offences without distinction

${ }^{136}$ Prosecutor v. Delalic et al., Decision on the Prosecution's Oral Requests for the Admission of Exhibit 155 into Evidence and for an Order to Compel the Accused, Zdravko Mucic, to Provide a Handwriting Sample, Case No. IT-96-21, 19 January 1998.

${ }^{137}$ Prosecutor v. Delalic et al; Prosecutor v. Halilovic, Decision on Motion for Exclusion of Statement of Accused, Case No. IT-01-48-T, 8 July 2005.

${ }^{138}$ R. 74(3)(c) ICC RPE; R. 75 ICC RPE.

${ }^{139}$ Prosecutor v. Norman, Decision on the Request of the Truth and Reconciliation Commission of Sierra Leone to Conduct a Public Hearing with Samuel Hinga Norman , Case No. SCSL-03-08-PT101, 29 October 2003, para. 14; Prosecutor v. Norman, Decision on Appeal by the Truth and Reconciliation Commission of Sierra Leone and Chief Samuel Hinga Norman against the Decision of His Lordship Justice Bankole Thompson to Deny the TRC's Request to Hold a Public Hearing with Chief Norman, Case No. SCSL-03-08-PT-122-I and II, 28 November 2003, para. 41.

${ }^{140}$ Saunders, supra note 57, 2065. 
from the most simple to the most complex'. ${ }^{141}$ However, the Court has subsequently departed from this stance. In Jalloh, ${ }^{142}$ in which the applicant, following arrest, was forced to regurgitate a bag of cocaine that was used as evidence against him at trial, the Court applied a four-factor test to determine whether the privilege had been violated, considering in turn the nature and degree of compulsion, the public interest in securing conviction, the existence of legal safeguards and the use to which the information was put. It thereby introduced a case-by-case approach to determining whether the privilege has been violated.

Versions of the Jalloh test have been applied in other cases, despite the very different scenarios involved. In the conjoined case of O'Halloran and Francis the Court noted that O'Halloran's situation was similar to that of Saunders, whereas Francis was considered closer to Funke and Heaney and McGuinness in each of which the applicant was fined for not providing information. ${ }^{143}$ Nevertheless, the Court considered the cases together and applied a three-stage version of the Jalloh test, excluding the public interest, and permitted limitation of the privilege in a case involving the statutory obligation on vehicle owners under UK law to provide details of the driver in certain circumstances. The limitation was considered justified due to the direct nature of the compulsion used to obtain information from O'Halloran and to attempt to obtain information from Francis: both had been informed in the Notice of Prosecution that they were required to provide the information sought and that failure to do so was a criminal offence punishable by a fine and driving penalties. ${ }^{144}$ The fact

\footnotetext{
${ }^{141}$ Ibid; Heaney and McGuinness, supra note 77, para. 57-58.

${ }^{142}$ Jalloh v. Germany, Decision of 11 July 2006, (2006) 44 EHRR 32, para. 118-121.

${ }^{143}$ O'Halloran and Francis, supra note 122, para 43.

${ }^{144}$ Ibid, 56-7.
} 
that the compulsion formed part of a regulatory scheme that fairly imposes obligations on drivers in order to impose road safety was significant. The Court also noted that the information required under the scheme was simple, specific and restricted and there was a legal safeguard in the form of a defence of due diligence. ${ }^{145}$ The nature and degree of the compulsion, the existence of legal safeguards and the use to which the information was put ${ }^{146}$ justified departure from the privilege. ${ }^{147}$

National courts have also grappled with limitations, particularly in cases where a person is penalized for failure to comply with a duty to provide information. In Brown v. Stott, ${ }^{148}$ which concerned a traffic statutory self-reporting regime, the reporting requirement was upheld by the Judicial Committee of the Privy Council. Lord Bingham balanced the public interest in dealing with the misuse of vehicles on the roads against the intrusion on the suspect's interests. He considered that the single question asked and the moderate, non-custodial penalty provided by the statute for refusing to respond did not overall impinge upon the fairness of the proceedings. ${ }^{149}$ The U.S. Supreme Court made similar findings in California v. Byers, adopting a balancing approach to resolve the tension between the state and individual interests. It held that compliance with a regulatory, non-criminal statute in which self-reporting is indispensable to its fulfillment, where the burden is on the public at large and where

\footnotetext{
${ }^{145}$ Ibid.

${ }^{146}$ Heaney and McGuinness, supra note 77, paras. 51-55.

${ }^{147}$ Ibid. On this decision see Ashworth, supra note 48, at 764.

148 [2001] 1 AC 681 (PC).

${ }^{149}$ For critique see Berger, supra note 67. Balancing can also been seen in the case law of England and Wales, see $R$. v. Mushtaq [2005] UKHL 25; $R$ v. K (A) [2010] QB 343; R. v Kearns [2002] EWCA Crim. 748.
} 
the possibility of incrimination is not substantial, does not infringe the privilege. ${ }^{150}$ Yet, in the Canadian case of $R$. v. White, ${ }^{151}$ where the prosecution sought to admit as evidence the compelled statements of the defendant obtained through statutory selfreporting laws, the opposite conclusion was reached. Although the Supreme Court also sought to balance the privilege against individual and societal interests, it held that use of the compelled self-identification report would be a violation of the privilege and therefore the Charter. ${ }^{152}$

Although these cases give rise to different outcomes, together they suggest that a range of factors is relevant in determining whether a particular instance of selfincrimination amounts to a violation. As with other aspects of the privilege, the balancing ${ }^{153}$ of various factors in reaching decisions makes it difficult to assess whether disclosures made in accountability schemes will be protected. On the one hand, the case law suggests that limitation may not be permitted in relation to transitional accountability schemes. Limitations appear typically to have been permitted where the consequences of self-incrimination are insubstantial, such as fines and non-custodial penalties, the information required is narrow and specific and is to be used for a pre-determined and restricted purpose, such as under motoring statutory self-reporting regimes. In transitional accountability schemes, the

\footnotetext{
${ }^{150}$ California v. Byers 402 U.S. 424 (1971) 402, 427-431, confirmed in Hiibel v. Sixth Judicial District of Nevada, Humboldt County et al, 542 US 177 (2004).

${ }^{151}$ [1999] 2 SCR 417.

${ }^{152}$ Ibid, 71. See too Berger supra note 67.

${ }^{153}$ On the balancing approach see Berger, ibid; D. Meyerson, 'Why Courts Should Not Balance Rights Against the Public Interest', (2007) 31 Melbourne University Law Review 873, 902.
} 
consequences of self-incrimination may be substantial as disclosure of involvement in past violations is a requirement of participation. The information required is broad and detailed as 'full disclosure' is very often a determinative criterion of eligibility for amnesty. In addition, the use(s) to which disclosures might be put is undetermined. In South Africa, the TRC Act prevented the use of disclosures in proceedings other than those of the truth commission itself. However, in Timor Leste, disclosures were used not only as the basis for CRP but were also shared with prosecuting bodies. The legislation in Kenya and Nepal permits the sharing of incriminating statements between truth seeking and prosecutorial institutions, with no apparent bars on the use of statements to further criminal cases. Thus, the use of disclosures may be wide and varied. In light of these considerations, limitation of the privilege through the use of incriminating disclosures in subsequent proceedings may well be deemed illegitimate.

Consideration of the public interest raises different, and more difficult, issues. The wrongdoing disclosed in the course of accountability schemes is wide-ranging, involving human rights violations related to physical integrity and property destruction. There may be an argument that where amnesty for such crimes is not granted due to the lack of a political objective, it is in the public interest for those responsible to be prosecuted and, if found guilty, punished and that such an interest justifies some restriction of the privilege through the use of self-incriminating statements. At the same time, it is also in the public interest for former perpetrators to participate within accountability schemes in order for transitional objectives around accountability to be achieved and to lay the foundations for a peaceful and reconciled future. If perpetrators suspect that there is a possibility that amnesty will be refused and that their disclosures might then be used to further investigations or employed 
against them in subsequent trials they will be less likely to participate, thereby limiting the prospects for reconciliation. ${ }^{154}$ Again, therefore, in the interests of ensuring the efficacy of truth seeking procedures and maximizing the possibilities for reconciliation through accountability schemes the privilege should be protected without limitation.

\section{Use-immunity as a solution}

One potential solution to the problem of how to maximize truth seeking and reconciliation goals through participation within accountability schemes, which are by their nature dependent on the disclosure of self-incriminating statements, might be to afford use-immunity to those disclosures. Granting use-immunity to compelled disclosures in subsequent criminal prosecutions is a compromise in many legal systems. ${ }^{155}$ It has also been suggested as a solution to the use by prosecutorial bodies of statements obtained by truth commissions under powers of compulsion. It has been argued that investigative authorities should be able to use compelled statements to further investigations, provided that they can ultimately prove that the evidence offered at a future trial could reasonably have been discovered in the absence of the compelled testimony. ${ }^{156}$ Yet, as Berger notes, use-immunity might prevent evidentiary use of compelled statements in the suspect's prosecution, but it leaves the

\footnotetext{
${ }^{154}$ See e.g., PRIDE, "Ex-Combatant Views of the Truth and Reconciliation Commission and the Special Court for Sierra Leone”, A Study in Partnership with the International Center for Transitional Justice, (2002), 19.

${ }^{155}$ For examples see Choo, supra note 113, App. 2.

${ }^{156}$ Freeman, supra note 9, 253.
} 
authorities aware of the illegal activities learned through disclosure. Unless the immunity extends to both evidentiary and non-evidentiary uses of the information compelled from the suspect, it cannot provide adequate protection. ${ }^{157}$

Derivative use-immunity, which pertains to both evidentiary and non-evidentiary uses of compelled information, is not routinely available within many domestic systems. The admissibility of statements is typically considered on a case-by-case basis and excluded where deemed to impinge upon the overall fairness of proceedings. ${ }^{158}$ In the context of transitional accountability schemes, derivative use immunity can be an essential element of safeguarding both individual rights and the efficacy of the initiative itself. It can bolster individual rights by preventing the use of incriminating statements in any subsequent criminal investigations or proceedings. This is turn can facilitate participation within accountability initiatives by dispelling concern among potential participants that their statements might later be used against them, thereby maximizing the potential of such schemes to make a meaningful contribution to accountability and longer term stability and reconciliation. For this to operate effectively, derivative use immunity must be guaranteed within the domestic legislation that creates the accountability scheme. To leave this to prosecuting bodies may perpetuate uncertainty among potential participants, risking their involvement within the scheme altogether.

\footnotetext{
${ }^{157}$ Berger, supra note 67, 34 .

${ }^{158}$ On national approaches see Choo, supra note 113, 35-9. See too, M. O’Boyle, 'Freedom from SelfIncrimination and the Right to Silence: A Pandora's Box', in P. Mahoney et al (eds.), Protection des Droits de l'homme: La Perspective Europeenne: Melanges a la Memoire de Rolv Ryssdal, (2000), 1029.
} 
Some may contend that in the interests of delivering criminal justice for past crimes, self-incriminating statements should be available for use in the furtherance of criminal cases, both in relation to investigations and in use as evidence, where amnesty has been denied. When this issue was considered in relation to self-incriminating testimony obtained in traditional truth seeking procedures, there seemed to be some agreement that it should be inadmissible in subsequent proceedings against the person concerned. ${ }^{159}$ However, there was also a body of support for denying use-immunity to compelled disclosures, suggesting that the use of information in this way is not believed to fall foul of fair trial standards. ${ }^{160}$ Nevertheless, and legal technicalities aside, a sense of injustice arises where individuals are required to confess their involvement in past crimes, often without a right to legal advice, in order to participate in one process only to be found ineligible for inclusion in that process and prosecuted in relation to the crimes they have disclosed. Such a situation cannot easily be reconciled with notions of leaving behind past injustice and the promotion of a human rights culture that accountability scheme establishment is intended to represent. Again, this supports the contention that, in the interests of the efficacy and integrity of the accountability scheme itself, the sharing with prosecutorial bodies of self-incriminating disclosures ought to be prohibited.

\footnotetext{
${ }^{159}$ M. Wierda, P. B. Hayner and P. van Zyl, Exploring the Relationship Between the Special Court and the Truth and Reconciliation Commission of Sierra Leone, International Center for Transitional Justice, (2002), 12.

${ }^{160}$ Amnesty International, Truth, Justice and Reparation: Establishing an Effective Truth Commission, AI Index: POL 30/009/2007, 11 June 2007, 32.
} 


\section{Conclusion}

Accountability schemes aimed at the reintegration of low-level perpetrators are an important element of transitional justice programmes and are believed to make a significant contribution to the long-term stability and reconciliation of transitional states. To deny those upon whose participation they depend procedural rights, is to risk the very efficacy of the schemes themselves. The possibility of self-incriminating statements being passed to prosecutorial bodies either to further criminal investigations or for use in later trials may well inhibit participation within these schemes, limiting the possibilities for holding lower level perpetrators to account. It will also likely raise questions about the integrity of the accountability scheme as there is something unsettling about purporting to require disclosure for one purpose only to use it for another.

It remains difficult to determine categorically whether the privilege offers protection to those who make self-incriminating disclosures in the course of participation within transitional accountability schemes. This article suggested that through a reconceptualization and broadening of the concept of compulsion, the privilege can include the situation under consideration here. Admittedly, however, providing protection on the basis of the privilege to those who make self-incriminating disclosures in accountability schemes is currently problematic due to judicial understandings of compulsion, which do not easily encompass this scenario. While the privilege might ultimately prevent the use of disclosures against relevant individuals within subsequent trials, such an eventuality is in itself undesirable. Challenges by the defence to the use of self-incriminating disclosures on fair trial 
grounds will likely cause delay or perhaps even derail cases altogether. Failed prosecutions of serious human rights violations are not in the interests of transitional states or those of victims.

The solution appears to lie in granting use-immunity to self-incriminating disclosures, preventing their use in evidentiary and non-evidentiary proceedings. Future accountability schemes should therefore be designed with an inbuilt system of safeguards that provide use-immunity to self-incriminating disclosures. Such safeguards ought to be laid down in the legislation that creates and regulates the accountability scheme, which will often also be the truth commission enacting legislation. While conclusions on immunity typically lie in the realm of prosecuting bodies, this is not a solution to the current issue. The uncertainty generated by such an arrangement may impede the efficacy of the accountability scheme by inhibiting participation among those who fear the possibility of prosecution and the pending nature of the decision on immunity. Providing for use-immunity from the outset within enacting legislation will not only ensure the upholding of individual rights, but maintain the integrity of accountability schemes themselves, while maximizing the potential for participation in and long term impact from them. 